\title{
Implementation of Counceling in Antenatal Care Services in Puskesmas Genuk of Semarang
}

\author{
Erna Widyastuti ${ }^{1)}$; Ngadiyono2) \\ ernawidyastuti@ymail.com
}

\begin{abstract}
Background: Maternal mortalirty was one of indicator in the succesfull development sector. Maternal Mortality rate in Central Java Province in 2016 was 109.65 per 100,000 live births, decreased in 2017 by 88.5 per 100,000 live births ( 475 cases), and decreased again in 2018 by 78.6 per 100,000 live births (421 cases). At the same time Semarang city also get decreased. There has been a decreased in cases, 23 cases in 2017 to 19 cases in 2018. The aim of this study was to describe antenatal care services in Puskesmas Genuk.

Methods: This study was qualitative and quantitative descriptive research. The design of this research was sequential explanatory designs. The population in this study was pregnant woman and Midwife in Puskesmas Genuk Semarang city and were collected by use purposive sampling. The Researcher collect the data use Indepth interview and analyze the result.

Results: The Result of this study showed that Midwifery were dominated in middle age (30 year old) and experience more than tenth years (10 years). Midwives knows detail about counseling at ANC services, but have not yet applied the sequences or principles of counseling in carrying out counseling according to the ability of the research subject and according to the needs of the patient. Pregnant mother were classified in diffrents type of risk and they were remember the counceling from Midwife and can answer the question relate to it.

Conclusion: All the Midwife were know about giving advice through counceling method, but they still need to use the principal practice in delivering service.

Keyword : counceling service. Midwife, Pregnant Woman

1,2) Poltekkes Kemenkes Semarang, Indonesia

Jl. Tirtoagung, Pedalangan, Banyumanik
\end{abstract}

Background. Number of mother mortality at Central Java Province in 2004 showed increased to $126,55 / 100.000$. This rate also showed in Semarang city in the same years increased to 33 mother. According to the situation government used WHO regulation to decrease the Mortality rate by doing Antenatal Care Services. This service are concent on tenth number of procedure to give the best standart according to WHO (2006). The researcher had field case study about the Antenatal Care Service in one of Puskesmas in Semarang City, and they found that there were a gap in giving counceling service for pregnant mother.

Midwife as the health provider were not completely use the principal standart in giving a counceling service through pregnant mother. The aim of this study is to describe the implementation in giving an advice in antenatal care service in Puskesmas Genuk

Methods. This study is descriptive quantitative and qualitative research. Researcher will use sequential explanatory design for collect the data. This study will be conduct at Puskesmas Genuk in 2014. The researcher use purposive sampling method to collect population and the sampel data. The sampel is midwife and pregnant woman. The data measurement of this study use deep interview for primer data and Clinical record were collect as seconder data. The researcher analyze will use univariat analyzer and the data will be process by analyze the content by collect the data, make a resume, will display in narrative and conclusion. To keep the ethic of the research the name and the picture of respondent will show in symbol or keyword.

Result and Discussion. Research results can be observed in this section. 
Table 1. Distribution of Midwife's Education, Age, and work length

\begin{tabular}{llll}
\hline $\begin{array}{l}\text { Midwife } \\
\text { number }\end{array}$ & Age & Education & $\begin{array}{l}\text { Work } \\
\text { length }\end{array}$ \\
\hline 4 & $30-$ & Bachelor (2) & 29 \\
& 50 & Diploma (2) & years(1) \\
& & & 12 years \\
& & & $(3)$
\end{tabular}

Table 2. Distribution of Pregnant woman's by Age, Education and Parity

\begin{tabular}{llll}
\hline $\begin{array}{l}\text { Pregnant } \\
\text { womans }\end{array}$ & Age & Education & $\begin{array}{c}\text { Par } \\
\text { ity }\end{array}$ \\
\hline 4 & $17(1)$ & $\begin{array}{l}\text { Elementary (1) } \\
\text { Junior High(2) }\end{array}$ & 2 \\
& $20-35(3)$ & Senior High (1) &
\end{tabular}

The overview of Midwife knowledge about counceling service

Midwife were know about the principal practice of giving a counceling but they were not use it properly.

The overview of pregnant woman's knowledge about counceling.

The advice for pregnant womans are deliver by Midwife, but for some situation respondent confused about the priority. In other word, pregnant woman accept the advice without any hesitation. In giving advice process Midwife must give change for the pregnant woman for ask the thing she need to know, or midwife give evaluation about pregnant woman understanding about the advice.

The description of the provision of counseling services.

Antenantal care were done properly by midwife, but midwife are not allow or not suggest husband of the pregnant woman join while her wife were examined. The effect is husband will not know about the realtime condition of her wife.

The description of counceling Implementation in Antenatal Care Service.

Six (6) respondents said that the service was done by midwife but the service are not using the principal not perfectly match because the husband are not join the conversation or examine.

Conclusion and Suggestions. Based on the result, all the service in antenatal care were done properly by midwife but it were not completely use correct principal. The counseling method chosen by the midwife was not practiced systematically, it was not in accordance with the instructions for counseling pregnant women, which included: greeting, asking, describing, helping, explaining, and repeating information. Information is not conveyed in detail, only in the form of brief information on how to deal with complaints of pregnant women. The counceling were not gave in certain priority, it caused pregnant woman were not accept the advice based on her problem. In antenatal care service the researcher hope husband of the mother are allowed to see and accompanie the mother while she get counceling It is recommended to develop the next research about the implementation of counceling in primary health service for pregnant woman in other research.

Acknowledgements. Thanks to the researchers say to all those who have helped in completing this research.

\section{References}

Bungin, B. 2011. Metode Penelitian Kualitatif. Raja Grapindo Prasaja. Jakarta

Dinas Kesehatan Kota Semarang, 2014. Profil Kesehatan Kota Semarang tahun 2014

Dinas Kesehatan Kota Semarang, 2018. Profil Kesehatan Kota Semarang tahun 2018

Dinas Kesehatan Propinsi Jawa Tengah, 2014. Profil Kesehatan Propinsi Jawa Tengah Tahun 2014

Dinas Kesehatan Propinsi Jawa Tengah, 2018. Profil Kesehatan Propinsi Jawa Tengah Tahun 2018.

Deasy Mariyani, 2008. Faktor-Faktor yang Mempengaruhi Pelaksanaan Pelayanan Antenatal Sesuai Standar Pelayanan Kebidanan oleh Bidan Desa di Kabupaten Bima Tahun 2010. http://eprints.undip.ac.id/28543/, access in 26 Februari 2016 
Kemenkes RI, 2010. Pelayanan ANC Terpadu.

Mieke, 2013. Analisis Implementasi Program Pelayanan Antenatal Terpadu pada Ibu Hamil dengan Malaria di Puskesmas Tobelo Kabupaten Halmahera Utara Provinsi Maluku Utara. Masters thesis, Universitas Diponegoro. http://eprints.undip.ac.id/39878/2/Abstra k Anna Mieke MKIA Januari 2013.pdf, accecc in 26 Februari 2016

Martha K, 2008. Implementasi Pelayanan Antenatal Care Pada lbu Hamil Di Klinik Siti Aisyah Lubuk Pakam Tahun 2008 http://repository.usu.ac.id/bitstream/123 456789/23758/7/Cover.pdf, diakses tanggal 26 Februari 2016

Moeleong, L J. 2011. Metodologi Penelitian Kualitatif. PT Remaja Rosda Karya. Bandung.

Purwaningrum, Yuniasih (2011) Analisis Implementasi Pemeriksaan Kadar Hemoglobin dalam Pelayanan Antenatal di Puskesmas Kabupaten Jember Propinsi Jawa Timur. Jurnal MIKM, Universitas Diponegoro http://eprints.undip.ac.id/33077/, tanggal 26 Februari 2016

Retno Heru, dkk. (2012). Konseling Ibu Hamil Pada BPM Dan Puskesmas di Kabupaten Bantul. https://jurnal.ugm.ac.id/jkki Volume 01 No. 03 September 2012
Sugiyono. 2010. Metode Penelitian Kuantitatif, Kualitatif. Alfabeta.

Bandung.Leonardo Chavane

WHO, 2006. Provision on Effective Antenatal Care

http://www.who.int/reproductivehealth/pub lications/maternal perinatal health/effecti ve antenatal care.pdf, diakses tanggal 26 Februari 2016

Stuart, G. W. and Laraira, M. T. (2005) Principles and Practice of Psychiatric Nursing. 8th Editio. Missouri: Mosby, Inc.

Videbeck, . L. (2010) Psychiatric-Mental Health Nursing. Sixth Edit. Philadelphia: Lippincott Williams \& Wilkins.

Wahyuni, S. E. (2010) Pengaruh Cognitive Behaviour Therapy terhadap Halusinasi Pasien di Rumah Sakit Jiwa Pemprovsu Medan. Universitas Indonesia. Available at: http://lib.ui.ac.id/detail.jsp?id=137113.

WHO (2019) Schizophrenia, Home/Newsroom/Fact sheets/ Detail. Available at: https://www.who.int/newsroom/fact-sheets/detail/schizophrenia. 